\title{
Design, Construction and Evaluation of a Web Application for the Teaching-Learning Process on Financial Mathematics
}

\author{
https://doi.org/10.3991/ijet.v15i08.12275 \\ Ricardo-Adán Salas-Rueda \\ Universidad Nacional Autónoma de México, Ciudad de México, México \\ ricardo.salaseicat.unam.mx
}

\begin{abstract}
This quantitative research aims to analyze the impact of the Web Application for the Teaching-Learning process on Simple Discount (WATLSD) through data science and machine learning (linear regression). The sample is composed of 42 students of the careers in Administration and Marketing who attended the Financial Mathematics course during the 2018 school year. The ADDIE model allows organizing the construction of the WATLSD through the stages of Analysis, Design, Development, Implementation and Evaluation. The results of machine learning indicate that the use of the WATLSD during the learning process positively influences the motivation, active role and development of mathematical skills. Likewise, data science establishes 3 predictive models on the use of the WATLSD in the educational field. Finally, advances in technology such as the WATLSD allow the creation of new virtual spaces for learning and teaching.
\end{abstract}

Keywords—Educational technology, Teaching, Learning, ICT, Data science, Machine learning

\section{Introduction}

Today, technology is changing the way of assimilating knowledge and developing the skills of students [1], [2]. In the 21st century, Internet is modifying the organization of school activities and educational practices [3], [4]. For example, web applications facilitate the personalization of learning through the consultation of information at any time and place [5].

The educational environment is changing because teachers are incorporating digital tools, web platforms and applications in school activities [6], [7]. Even educational institutions seek to create new virtual spaces to increase the motivation of students during the teaching-learning process [8], [9].

According to [10], Information and Communication Technologies (ICT) are essential to organize the school activities in the 21 st century. In fact, technology is transforming the way of managing the information and content of the courses [10], [11]. 
Teachers have the possibility of building new spaces for learning and teaching through technology [12], [13]. In fact, technological skills of students facilitate the incorporation of ICT into and out of the classroom [14], [15].

This quantitative research analyzes the use of the WATLSD in the teachinglearning process on financial mathematics (Simple Discount) through data science and machine learning.

The research questions are:

- What is the impact of the WATLSD in the teaching-learning process on the Simple Discount (development of mathematical skills, active role and motivation of the students)?

- What are the predictive models of the use of the WATLSD in the teaching-learning process?

\section{ICT in the Educational Field}

Technological advances such as web platforms and applications positively influence the teaching-learning process about music [16], mathematics [17], reading comprehension [18], engineering [19] and English language [20].

One of the challenges of teachers in the 21 st century is to develop the skills of students [21]. Various authors (e.g., [10], [16]) mention that the use of technology in school activities allows the development of skills.

For example, Moodle facilitates the creation of new virtual spaces that allow developing skills on music issues [16]. Similarly, web applications allow the development of grammatical skills in the course on Language Teaching [10]. Even the incorporation of web applications in the field of statistics favors the development of mathematical skills and active role of the students [5].

\subsection{Construction of educational web applications}

Various authors (e.g., [5], [18], [20], [22]) have built web applications in order to improve the teaching-learning process and develop the skills of students. For example, [20] designed and built a web application to facilitate the understanding of the alphabet and pronunciation of letters in the English language.

The benefits related to the incorporation of web applications in school activities are the consultation of the contents from any place and time [5]. Also, the use of web applications allows the customization of the educational process because students control the pace of learning ([10], [18], [22]). Even students have the advantage of using various technological tools such as educational platforms and web applications from smartphones, tablets and laptops ([20], [23], [24]).

For example, [22] created a web application to facilitate the assimilation of knowledge about reading and writing at the basic educational level. Similarly, [17] built the MaGrid application with the purpose of facilitating the teaching-learning process and developing mathematical skills at the basic educational level. 
[18] developed the Quráni application to facilitate reading comprehension considering the user profile with hearing problems. Even [5] built a web application to facilitate the development of mathematical skills in the field of statistics.

Web applications allow transforming the educational context because students have access to information at any time and place ([22], [18]). In fact, mobile devices facilitate the use of web applications during the teaching-learning process ([25], [26]).

\section{Methodology}

The objective of this quantitative research aims to analyze the impact of the WATLSD in the teaching-learning process on financial mathematics (Simple Discount) through data science and machine learning.

\subsection{Participants}

The sample is composed of 42 students (20 men and 22 women) of Administration $(\mathrm{n}=16,38.10 \%)$ and Marketing $(\mathrm{n}=26,61.90 \%)$ who studied Financial Mathematics course at a university in Mexico City during the 2018 school year.

The machine learning allows finding the linear regressions with $60 \%(\mathrm{n}=25$ students), $70 \%(\mathrm{n}=29$ students $)$ and $80 \%$ ( $\mathrm{n}=33$ students $)$ of training section to evaluate the research hypotheses.

In addition, $40 \%(\mathrm{n}=17$ students), $30 \%(\mathrm{n}=13$ students $)$ and $20 \%(\mathrm{n}=9$ students $)$ of the evaluation section allows identifying the accuracy of linear regressions on the impact of the WATLSD in the teaching-learning process.

\subsection{Procedure}

The procedure of this quantitative research began with the use of the ADDIE model to analyze the characteristics and needs of the students (See Table 1).

Table 1. Use of the ADDIE model

\begin{tabular}{|c|l|l|l|}
\hline No. & \multicolumn{1}{|c|}{ Stage } & \multicolumn{1}{|c|}{ Aspect } & \multicolumn{1}{c|}{ Description } \\
\hline \multirow{5}{*}{1} & Analysis & Course & Financial Mathematics \\
\cline { 3 - 4 } & & Unit & The Interest unit contains the topic on Simple Discount \\
\cline { 3 - 4 } & Objective & $\begin{array}{l}\text { The student will understand the calculation of the Simple } \\
\text { Discount }\end{array}$ \\
\cline { 3 - 4 } & Students & $\begin{array}{l}\text { The students attended the third semester of careers in Ad- } \\
\text { ministration and Marketing during the 2018 school year }\end{array}$ \\
\cline { 3 - 4 } & Problem & $\begin{array}{l}\text { The students of Administration and Marketing have difficul- } \\
\text { ty to assimilate the knowledge on the Simple Discount }\end{array}$ \\
\cline { 3 - 4 } & Design & $\begin{array}{l}\text { Design and construction of the WATLSD to facilitate the } \\
\text { learning process through simulation of data }\end{array}$ \\
\hline \multirow{3}{*}{2} & General objective & $\begin{array}{l}\text { The student will understand and use the formulas on the } \\
\text { Simple Discount in the practical context }\end{array}$ \\
\cline { 3 - 4 } & $\begin{array}{l}\text { Particular objec- } \\
\text { tives }\end{array}$ & $\begin{array}{l}\text { The student will understand the concepts of Nominal princi- } \\
\text { pal, Accumulated amount and Simple Discount }\end{array}$ \\
\hline
\end{tabular}




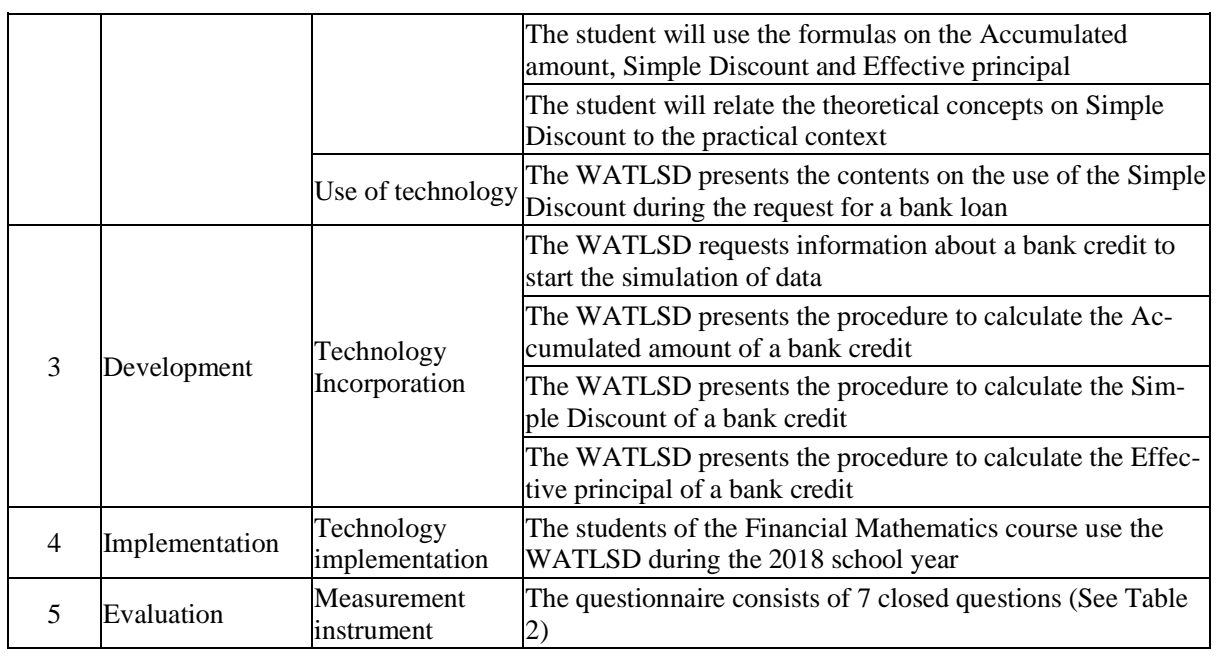

The WATLSD was built through HTML and the PHP programming language. The students of the Financial Mathematics course used this web application through the following address: http://sistemasusables.com/mf/descuento/inicio.html

The WATLSD requests information about a bank credit to start the simulation of data (See Fig. 1).

\section{Financial Mathematics Discount}

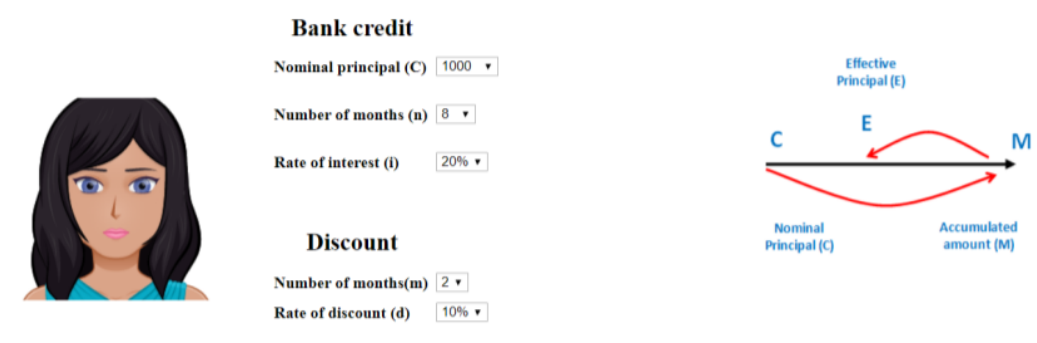

\section{Continue}

Fig. 1. Request for information in the WATLSD

The WATLSD presents the calculation of the Accumulated amount (See Fig. 2). 


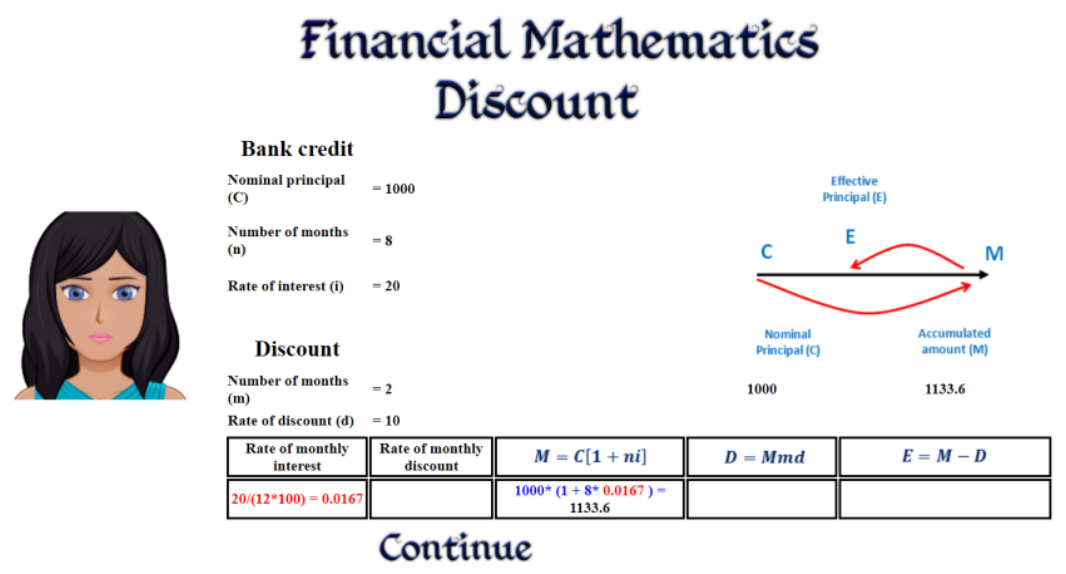

Fig. 2. Calculation of the Accumulated amount in the WATLSD

Fig. 3 shows the calculation of the Simple Discount in the WATLSD.

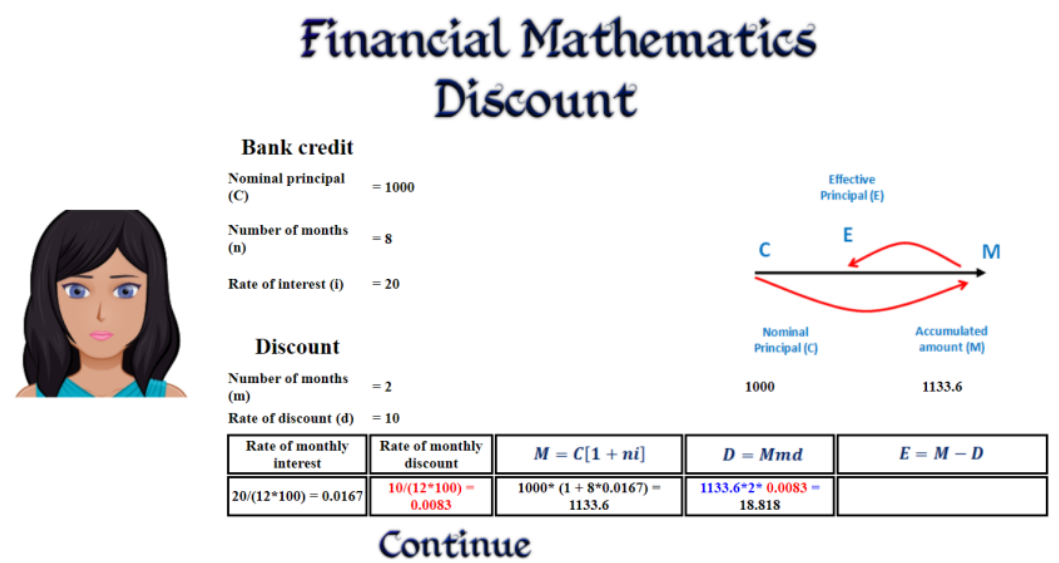

Fig. 3. Calculation of the Simple Discount in the WATLSD

The WATLSD presents the calculation of the Effective principal (See Fig. 4). 


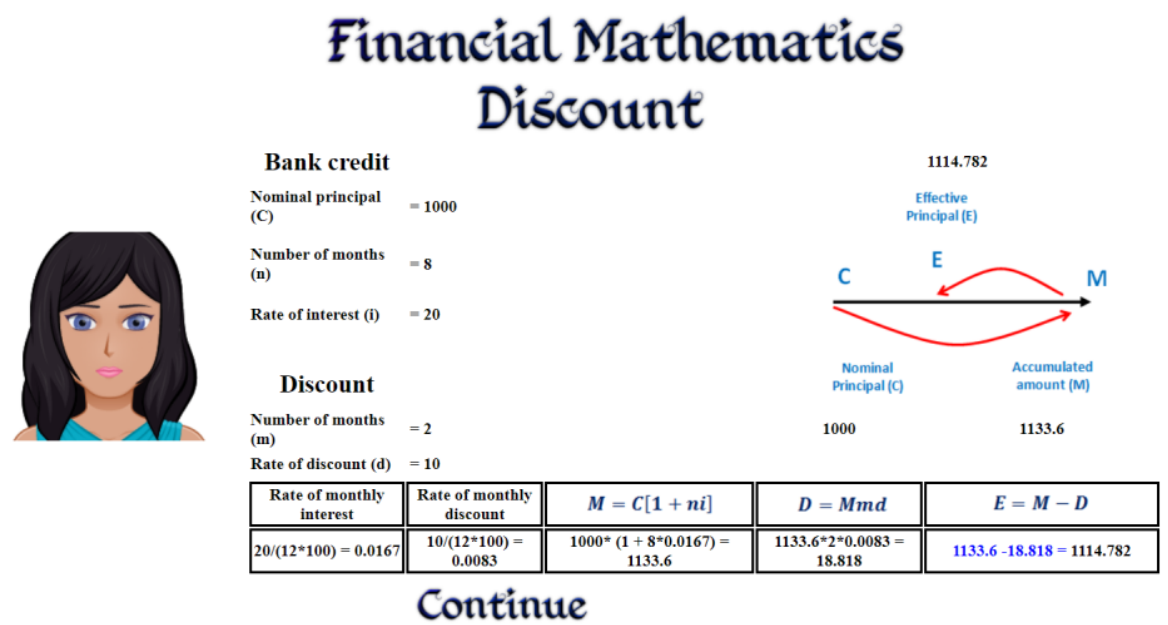

Fig. 4. Calculation of the Effective principal in the WATLSD

Fig. 5 shows the model of technological acceptance on the use of the WATLSD during the teaching-learning process.
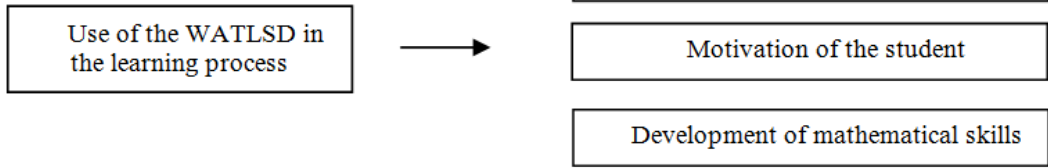

Fig. 5. Technological acceptance model on the use of the WATLSD

The research hypotheses are:

- Hypothesis 1 (H1): The use of the WATLSD during the learning process positively influences the active role of the student

- Hypothesis 2 (H2): The use of the WATLSD during the learning process positively influences the motivation of the student

- Hypothesis $3(\mathrm{H} 3)$ : The use of the WATLSD during the learning process positively influences the development of mathematical skills

On the other hand, data science allows the identification of the following predictive models on the use of the WATLSD in the educational process:

- Predictive model 1 on the WATLSD and active role of the student

- Predictive model 2 on the WATLSD and motivation of the student

- Predictive model 3 on the WATLSD and development of mathematical skills 


\subsection{Data analysis}

The Rapidminer tool allows performing the calculation of the machine learning (linear regression) to evaluate the research hypotheses and build the predictive models on the use of the WATLSD during the educational process of Simple Discount.

Machine learning divides the sample into two groups, that is, the training section $(60 \%, 70 \%$ and $80 \%)$ allows obtaining the linear regression and the evaluation section $(40 \%, 30 \%$ and 20\%) allows knowing the accuracy of linear regression (See Fig. 6).

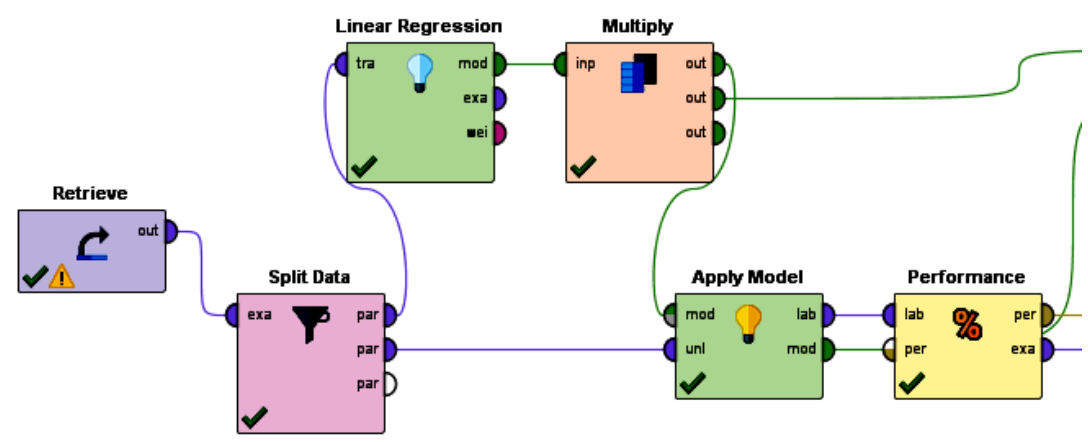

Fig. 6. Calculation of machine learning in the Rapidminer tool

The decision tree technique allows building the predictive models through the Rapidminer tool (See Fig. 7).

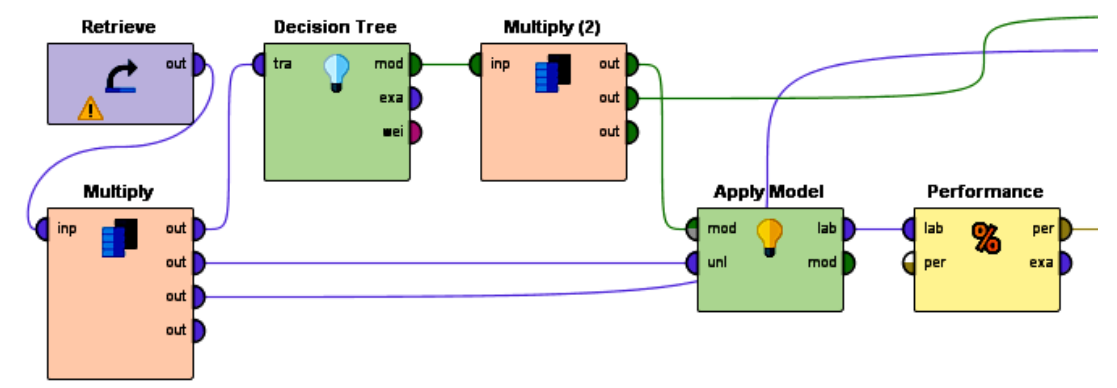

Fig. 7. Construction of predictive models in the Rapidminer tool

Finally, the SPSS software allows validating the measurement instrument by means of the Load Factor, Cronbach's Alpha, Average Variance Extracted (AVE) and Composite Reliability (CR).

\subsection{Data collection}

The measurement instrument (questionnaire) has 7 closed questions related to the use of the WATLSD in the Financial Mathematics course during the 2018 school year (See Table 2). 
Table 2. Questionnaire

\begin{tabular}{|c|c|c|c|c|c|c|}
\hline No. & Variable & Dimension & Question & Answer & $\mathbf{n}$ & $\%$ \\
\hline \multirow{9}{*}{1} & \multirow{9}{*}{$\begin{array}{l}\text { Profile of } \\
\text { the student }\end{array}$} & \multirow[t]{2}{*}{ Sex } & \multirow[t]{2}{*}{ 1. Indicate your sex } & Man & 20 & $47.62 \%$ \\
\hline & & & & Woman & 22 & $52.38 \%$ \\
\hline & & \multirow[t]{2}{*}{ Career } & \multirow[t]{2}{*}{ 2. Indicate your career } & Administration & 16 & $38.10 \%$ \\
\hline & & & & Marketing & 26 & $61.90 \%$ \\
\hline & & \multirow{5}{*}{ Age } & \multirow{5}{*}{ 3. Indicate your age } & 19 years & 30 & $71.43 \%$ \\
\hline & & & & 20 years & 7 & $16.67 \%$ \\
\hline & & & & 21 years & 4 & $9.52 \%$ \\
\hline & & & & 22 years & 0 & $0.00 \%$ \\
\hline & & & & 23 years & 1 & $2.38 \%$ \\
\hline \multirow{17}{*}{2} & \multirow{17}{*}{ WATLSD } & \multirow{4}{*}{$\begin{array}{l}\text { Learning } \\
\text { process }\end{array}$} & \multirow{4}{*}{$\begin{array}{l}\text { 4. The WATLSD improves the } \\
\text { learning process on financial } \\
\text { mathematics }\end{array}$} & Too much (1) & 25 & $59.52 \%$ \\
\hline & & & & Much (2) & 17 & $40.48 \%$ \\
\hline & & & & Little (3) & 0 & $0.00 \%$ \\
\hline & & & & Too little (4) & 0 & $0.00 \%$ \\
\hline & & \multirow{4}{*}{ Active role } & \multirow{4}{*}{$\begin{array}{l}\text { 5. The WATLSD improves the } \\
\text { active role of the student }\end{array}$} & Too much (1) & 36 & $85.71 \%$ \\
\hline & & & & Much (2) & 6 & $14.29 \%$ \\
\hline & & & & Little (3) & 0 & $0.00 \%$ \\
\hline & & & & Too little (4) & 0 & $0.00 \%$ \\
\hline & & \multirow{5}{*}{ Motivation } & \multirow{5}{*}{$\begin{array}{l}\text { 6. The WATLSD improves the } \\
\text { motivation of the student }\end{array}$} & & & \\
\hline & & & & Too much (1) & 26 & $61.90 \%$ \\
\hline & & & & Much (2) & 15 & $35.71 \%$ \\
\hline & & & & Little (3) & 1 & $2.38 \%$ \\
\hline & & & & Too little (4) & 0 & $0.00 \%$ \\
\hline & & \multirow{4}{*}{$\begin{array}{l}\text { Development } \\
\text { of mathemati- } \\
\text { cal skills }\end{array}$} & \multirow{4}{*}{$\begin{array}{l}\text { 7. The WATLSD improves the } \\
\text { development of mathematical } \\
\text { skills }\end{array}$} & Too much (1) & 24 & $57.14 \%$ \\
\hline & & & & Much (2) & 17 & $40.48 \%$ \\
\hline & & & & Little (3) & 1 & $2.38 \%$ \\
\hline & & & & Too little (4) & 0 & $0.00 \%$ \\
\hline
\end{tabular}

The Load Factor (>0.50), Cronbach's Alpha (>0.70) and Composite Reliability (> $0.70)$ values guarantee the reliability of the questionnaire [27]. Table 3 shows that the values on the Load Factor exceed 0.650, that is, Learning Process (0.860), Active Role (0.735), Motivation (0.757) and Development of Mathematical Skills (0.654). Also, the values of Cronbach's Alpha (0.731) and Composite Reliability (0.840) are greater than 0.70 . 
Table 3. Validation of the questionnaire

\begin{tabular}{|c|c|l|c|c|c|c|}
\hline No. & Variable & \multicolumn{1}{|c|}{ Dimension } & $\begin{array}{c}\text { Load } \\
\text { Factor }\end{array}$ & $\begin{array}{c}\text { Cronbach's } \\
\text { Alpha }\end{array}$ & $\begin{array}{c}\text { Average Vari- } \\
\text { ance Extracted }\end{array}$ & $\begin{array}{c}\text { Composite } \\
\text { Reliability }\end{array}$ \\
\hline \multirow{3}{*}{1} & \multirow{2}{*}{ WATLSD } & 0.860 & & & \multirow{2}{*}{0} \\
\cline { 3 - 4 } & & Learning process & 0.735 & \multirow{2}{*}{0.731} & 0.570 & 0.840 \\
\cline { 3 - 4 } & Active role & 0.757 & & \\
\cline { 3 - 4 } & $\begin{array}{l}\text { Motivation } \\
\text { Sevelopment of Mathematical }\end{array}$ & 0.654 & & & \\
\hline
\end{tabular}

\section{$4 \quad$ Results}

The WATLSD improves too much $(n=25,59.52 \%)$ and much $(n=17,40.48 \%)$ the learning process about financial mathematics. Likewise, the results of machine learning with $60 \%, 70 \%$ and $80 \%$ of training indicate that the use of the WATLSD during the learning process positively influences the active role, motivation and development of mathematical skills (See Table 4).

Table 4. Results of machine learning

\begin{tabular}{|c|c|c|c|c|c|}
\hline No. & Hypothesis & Training & Linear regression & Conclusion & $\begin{array}{c}\text { Square } \\
\text { error }\end{array}$ \\
\hline \multirow{3}{*}{1} & \multirow{3}{*}{$\begin{array}{l}\text { H1: WATLSD } \rightarrow \\
\text { active role of the } \\
\text { student }\end{array}$} & $60 \%$ & $y=0.428 x+0.571$ & Accepted: 0.428 & 0.365 \\
\hline & & $70 \%$ & $y=0.444 x+0.555$ & Accepted: 0.444 & 0.372 \\
\hline & & $80 \%$ & $y=0.363 x+0.636$ & Accepted: 0.363 & 0.409 \\
\hline \multirow{3}{*}{2} & \multirow{3}{*}{$\begin{array}{l}\text { H2: WATLSD } \rightarrow \\
\text { motivation of the } \\
\text { student }\end{array}$} & $60 \%$ & $y=0.833 x+0.333$ & Accepted: 0.833 & 0.433 \\
\hline & & $70 \%$ & $\mathrm{y}=0.849 \mathrm{x}+0.300$ & Accepted: 0.849 & 0.489 \\
\hline & & $80 \%$ & $y=0.778 x+0.351$ & Accepted: 0.778 & 0.464 \\
\hline \multirow{3}{*}{3} & \multirow{3}{*}{$\begin{array}{l}\text { H3: WATLSD } \rightarrow \\
\text { development of math- } \\
\text { ematical skills }\end{array}$} & $60 \%$ & $y=0.436 x+0.841$ & Accepted: 0.436 & 0.456 \\
\hline & & $70 \%$ & $y=0.527 x+0.722$ & Accepted: 0.527 & 0.509 \\
\hline & & $80 \%$ & $y=0.422 x+0.881$ & Accepted: 0.422 & 0.439 \\
\hline
\end{tabular}

\subsection{Active role of the student}

The WATLSD improves too much $(n=36,85.71 \%)$ and much $(n=6,14.29 \%)$ the active role of the student (See Table 2). Likewise, the results of machine learning with $60 \%(0.428), 70 \%(0.444)$ and $80 \%(0.363)$ indicate that hypothesis 1 is accepted (See Table 4). Therefore, the use of the WATLSD during the learning process positively influences the active role of the student.

Fig. 8 shows the predictive model 1 on the use of the WATLSD in the educational context. For example, if the student thinks that the WATLSD improves much the learning process on financial mathematics, has an age $\leq 19.5$ years and is a man then the WATLSD improves much the active role of the student. 


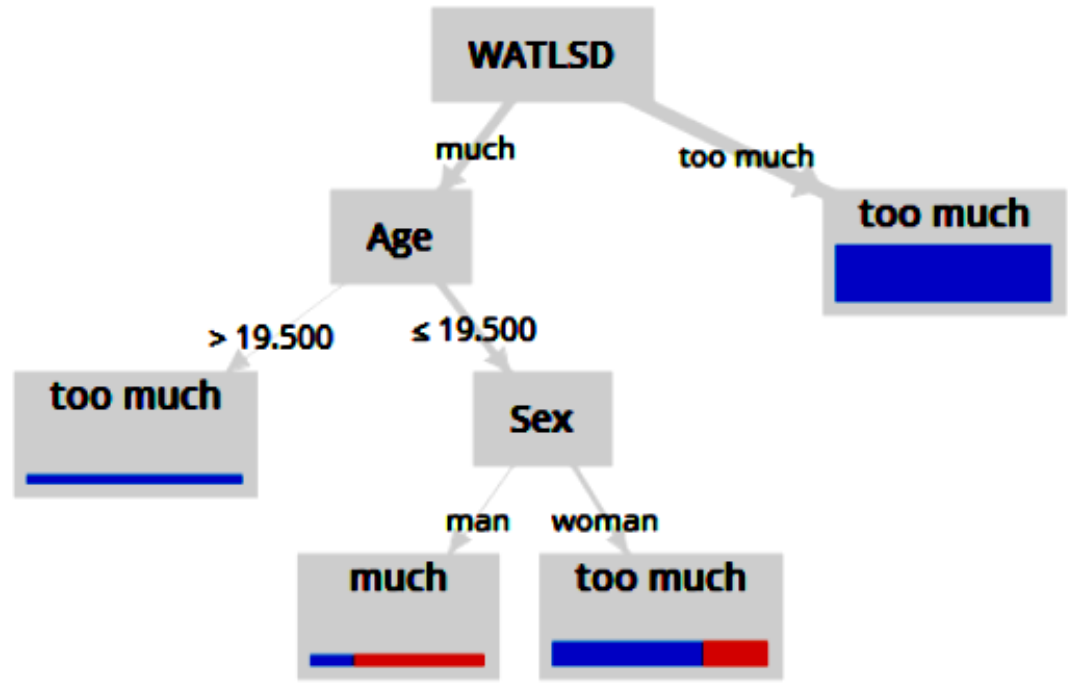

Fig. 8. Predictive model 1 on the use of the WATLSD

Predictive model 1 on the use of the WATLSD in the educational context has 4 conditions and has an accuracy of $90.48 \%$. For example, if the student thinks that the WATLSD improves much the learning process on financial mathematics, has an age $\leq 19.5$ years and is a woman then the WATLSD improves too much the active role of the student.

\subsection{Motivation of the student}

The WATLSD improves too much $(n=26,61.90 \%)$, much $(n=15,35.71 \%)$ and little $(n=1,2.38 \%)$ the motivation of the student (See Table 2$)$. Likewise, the results of machine learning with $60 \%(0.833), 70 \%(0.849)$ and $80 \%(0.778)$ indicate that hypothesis 2 is accepted (See Table 4). Therefore, the use of the WATLSD during the learning process positively influences the motivation of the student.

Fig. 9 shows the predictive model 2 on the use of the WATLSD in the educational context. For example, if the student thinks that the WATLSD improves much the learning process on financial mathematics and has an age > 19.5 years then the WATLSD improves much the motivation of the student. 


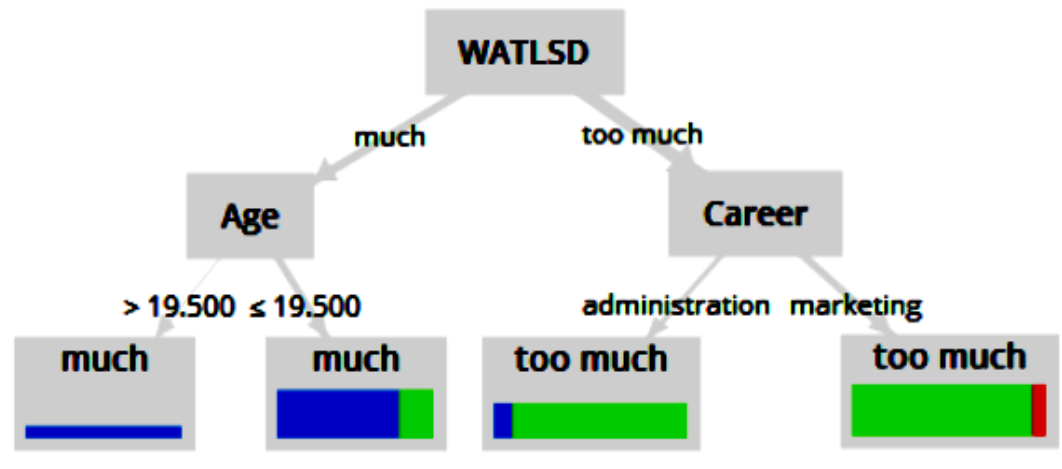

Fig. 9. Predictive model 2 on the use of the WATLSD

Predictive model 2 on the use of the WATLSD in the educational context has 4 conditions and has an accuracy of $88.10 \%$. For example, if the student thinks that the WATLSD improves too much the learning process on financial mathematics and takes the career of Administration then the WATLSD improves too much the motivation of the student.

\subsection{Development of mathematical skills}

The WATLSD improves too much $(\mathrm{n}=24,57.14 \%)$, much $(\mathrm{n}=17,40.48 \%)$ and little $(n=1,2.38 \%)$ the development of mathematical skills (See Table 2). Likewise, the results of machine learning with $60 \%(0.436), 70 \%(0.527)$ and $80 \%(0.422)$ indicate that hypothesis 3 is accepted (See Table 4). Therefore, the use of the WATLSD during the learning process positively influences the development of mathematical skills.

Fig. 10 shows the predictive model 3 on the use of the WATLSD in the educational context. For example, if the student thinks that the WATLSD improves much the learning process on financial mathematics and has an age $\leq 19.5$ years then the WATLSD improves much the development of mathematical skills. 


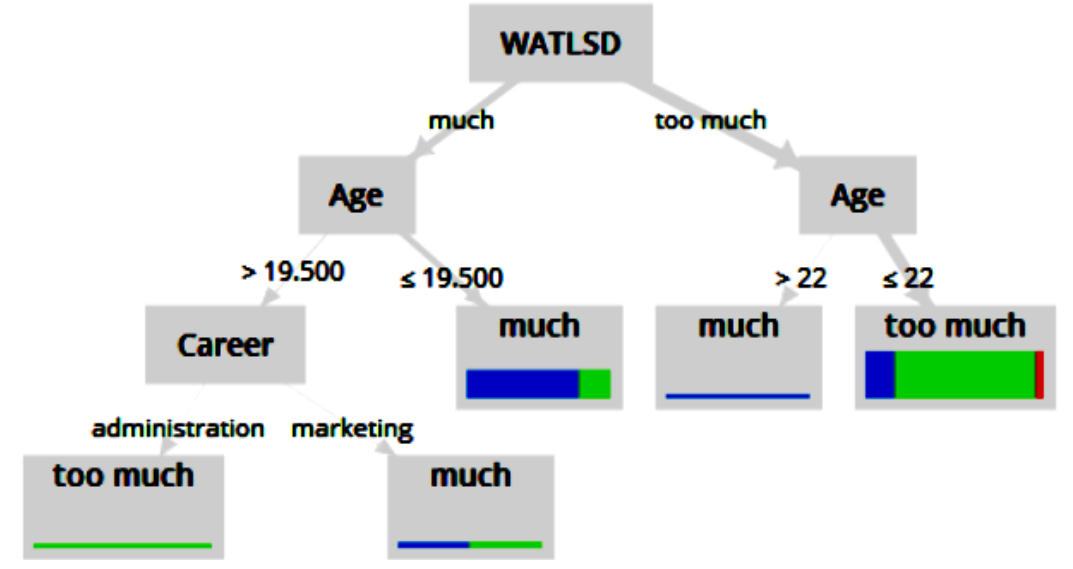

Fig. 10.Predictive model 3 on the use of the WATLSD

Predictive model 3 on the use of the WATLSD in the educational context has 5 conditions and has an accuracy of $78.57 \%$. For example, if the student thinks that the WATLSD improves too much the learning process on financial mathematics and has an age $\leq 22$ years then the WATLSD improves too much the development of mathematical skills.

\section{Discussion}

Today, technology is changing the organization and implementation of school activities [13]. For example, the incorporation of web applications and digital tools in the teaching-learning process facilitates the assimilation of knowledge and development of skills.

\subsection{Active role of the student}

Most of the students in the Financial Mathematics course think that the WATLSD improves too much $(\mathrm{n}=36,85.71 \%)$ the active role of the student. Even the results of hypothesis 1 on machine learning with $60 \%, 70 \%$ and 80 training are greater than 0.360 . Therefore, the use of the WATLSD during the learning process positively influences the active role of the student.

Also, data science identifies 4 predictive conditions on the use of the WATLSD and active role of the student, which are distributed in the Too much $(n=2)$ and Much $(n=2)$ categories.

\subsection{Motivation of the student}

Most of the students in the Financial Mathematics course think that the WATLSD improves too much $(n=26,61.90 \%)$ the motivation of the student. Even the results of 
hypothesis 2 on machine learning with $60 \%, 70 \%$ and 80 training are higher than 0.770 . Therefore, the use of the WATLSD during the learning process positively influences the motivation of the student.

Also, data science identifies 4 predictive conditions on the use of the WATLSD and motivation of the student, which are distributed in the Too much $(\mathrm{n}=2)$ and Much $(n=2)$ categories.

\subsection{Development of mathematical skills}

Most of the students in the Financial Mathematics course think that the WATLSD improves too much $(n=24,57.14 \%)$ the development of mathematical skills. Even the results of hypothesis 3 on machine learning with $60 \%, 70 \%$ and 80 training are greater than 0.420 . Therefore, the use of the WATLSD during the learning process positively influences the development of mathematical skills.

Data science identifies 5 predictive conditions on the use of the WATLSD and development of mathematical skills, which are distributed in the Too much $(\mathrm{n}=2)$ and Much $(\mathrm{n}=5)$ categories.

The WATLSD facilitates the teaching-learning process on the Simple Discount in the Financial Mathematics course through the detailed presentation of the mathematical calculations. In fact, the motivation of the student is the factor that has the greatest positive relationship with the use of the WATLSD during the learning process. On the other hand, the active role of the student is the factor that has the least positive relationship with the use of the WATLSD during the learning process.

The predictive models 1 (90.48\%), $2(88.10 \%)$ and $3(78.57 \%)$ on the use of the WATLSD during the learning process have an accuracy greater than $78.50 \%$. Finally, this research shares the ideas of various authors (e.g., [1], [12]) on the fundamental role of technology in the educational field. In particular, the WATLSD allows innovating school activities in the Financial Mathematics course.

\section{Conclusion}

Universities are transforming the teaching-learning process through the construction of new educational virtual spaces. In particular, the WATLSD is a web application that facilitates the educational process on Simple Discount through the simulation of data.

The results of machine learning indicate that the use of the WATLSD during the learning process improves the active role, motivation and development of mathematical skills. Likewise, data science identifies the predictive conditions on the use of the WATLSD in the Financial Mathematics course.

The limitations of this quantitative research are related to the contents of the WATLSD on Simple Discount. Therefore, future research may analyze the impact of technological tools during the teaching-learning process on Simple Interest, Compound Interest, Amortizations and Annuities. 
This quantitative research recommends the design and construction of educational web applications in order to improve teaching-learning conditions. For example, the WATLSD allows the students of the Financial Mathematics course to consult the contents at any time and place.

The implications of this study are the benefits of using technological tools in school activities. In particular, the WATLSD presents the mathematical procedure to facilitate the assimilation of knowledge about the Simple Discount. In conclusion, teachers can create new educational experiences through the construction and use of web applications.

\section{$7 \quad$ References}

[1] Magen-Nagar, N., Shachar, H., \& Argaman, O. (2019). Changing the Learning Environment: Teachers and Students' Collaboration in Creating Digital Games. Journal of Information Technology Education: Innovations in Practice, 18, 61-85. https://doi.org/10.28945/4405

[2] Muhisn, Z. A., Ahmad, M., Omar, M., \& Muhisn, S. A. (2019). The Impact of Socialization on Collaborative Learning Method in E-Learning Management System (eLMS). International Journal of Emerging Technologies in Learning, 14(20), 137-148. https://doi. org/10.3991/ijet.v14i20.10992

[3] Al-Azawei, A. (2019). What Drives Successful Social Media in Education and E-learning? A Comparative Study on Facebook and Moodle. Journal of Information Technology Education: Research, 18, 253-274. https://doi.org/10.28945/4360

[4] McGuinness, C. \& Fulton, C. (2019). Digital Literacy in Higher Education: A Case Study of Student Engagement with E-Tutorials Using Blended Learning. Journal of Information Technology Education: Innovations in Practice, 18, 1-28. https://doi.org/10.28945/4190

[5] Salas-Rueda, R. A. (2019). Construction and evaluation of a web application for the educational process on Normal Distribution considering the science of data and machine learning. Research in Learning Technology, 27, 1-24. https://doi.org/10.25304/rlt.v27.2085

[6] Muljo, H. H., Perbangsa, A. S., \& Pardamean, B. (2019). Assessment of Online Learning Application for Health Education. International Journal of Online and Biomedical Engineering, 15(12), 69-80. https://doi.org/10.3991/ijoe.v15i12.11157

[7] Simelane-Mnis, S. \& Mji, A. (2019). Technology-engagement Teaching Strategy Using Personal Response Systems on Student's Approaches to Learning to Increase the Mathematics Pass Rate. Journal of Information Technology Education: Research, 18, 331-353. https://doi.org/10.28945/4393

[8] Rohatgi, A., Scherer, R., \& Hatlevik, O. E. (2016). The role of ICT self-efficacy for students' ICT use and their achievement in a computer and information literacy test. Computers \& Education, 102, 103-116. https://doi.org/10.1016/j.compedu.2016.08.001

[9] Senkbeil, M. \& Ihme, J. M. (2017). Motivational factors predicting ICT literacy: First evidence on the structure of an ICT motivation inventory. Computers \& Education, 108, 145 158. https://doi.org/10.1016/j.compedu.2017.02.003

[10] Romero-Oliva, M. F., Jiménez-Fernández, R., \& Heredia-Ponce, H. (2019). Analysis of the implementation of an educational program based on the mobile learning methodology. Texto Livre: Linguagem e Tecnologia, 12(2), 172-201. 
[11] Uribe, S. N. \& Vaughan, M. (2017). Facilitating student learning in distance education: a case study on the development and implementation of a multifaceted feedback system. Distance Education, 38(3), 288-301. https://doi.org/10.1080/01587919.2017.1369005

[12] Lee, S., Baek, J., \& Han, G. (2018). Effects of using a second-screen application on attention, learning, and user experience in an educational content. Interactive Learning Environments, 26(3), 289-307. https://doi.org/10.1080/10494820.2017.1324494

[13] Jeno, L. M., Grytnes, J. A., \& Vandvik, V. (2017). The effect of a mobile-application tool on biology students' motivation and achievement in species identification: A SelfDetermination Theory perspective. Computers \& Education, 107, 1-12. https://doi.org/10. 1016/j.compedu.2016.12.011

[14] Kibar, P. N., Sullivan, K., \& Akkoyunlu, B. (2019). Creatıng Infographics Based on the Bridge21 Model for Team-based and Technology-mediated Learning. Journal of Information Technology Education: Innovations in Practice, 18, 87-111. https://doi.org/10.2894 $\underline{5 / 4418}$

[15] Salas-Rueda, R. A., Salas-Rueda, E. P., \& Salas-Rueda, R. D. (2019). Students' perceptions about the use of the tablet in the classroom considering data science and machine learning. Campus Virtuales, 8(1), 75-86. https://doi.org/10.17993/dideinnedu.2019.46

[16] De-Oscar, S. C. \& Santos-Gomes, C. A. (2019). The use of technological resources and music language in approaching parents and children: an experience in the 1st cycle of musical education, Texto Livre: Linguagem e Tecnologia, 12(3), 1-12. https://doi.org/10.178 $\underline{\text { 51/1983-3652.12.3.37-48 }}$

[17] Pazouki, T., Cornu, V., Sonnleitner, P., Schiltz, C., Fischbach, A., \& Martin, R. (2018). MaGrid: A Language-Neutral Early Mathematical Training and Learning Application. International Journal of Emerging Technologies in Learning, 13(8), 4-18. https://doi.org/10. 3991/ijet.v13i08.8271

[18] Hanafi, Y., Hendrawan, H. J., \& Hakim, I. N. (2019). Accelerating Qurán Reading Fluency through Learning Using QURÁNI Application for Students with Hearing Impairments. International Journal of Emerging Technologies in Learning, 14(6), 110-132. https://doi.org/ 10.3991/ijet.v14i06.9863

[19] Uziak, J., Oladiran, M. T., Lorencowicz, E., \& Becker, K. (2018). Students' and Instructor's Perspective on the use of Blackboard Platform for Delivering an Engineering Course. Electronic Journal of e-Learning, 16(1), 1-15.

[20] McKenzie, S., Spence, A., \& Nicholas, M. (2018). Going on Safari: The Design and Development of an Early Years Literacy iPad Application to Support Letter-Sound Learning. Electronic Journal of e-Learning, 16(1), 16-29.

[21] Karnain, R., Rahman, S., Surat, S., \& Ali, M.T. (2019). Usability of M-PA21 Module to Improve Teachers' Metacognitive Regulation in Teaching and Application of 21st Century Basic Skills. International Journal of Emerging Technologies in Learning, 14(20), 87-105. https://doi.org/10.3991/ijet.v14i20.11462

[22] Barbosa-Vicente, R. \& Silva-Araujo, M. Y. (2017). Digital application: a contribution to the teaching-learning process. Texto Livre: Linguagem e Tecnologia, 10(2), 169-184. http ://dx.doi.org/10.17851/1983-3652.10.2.169-184

[23] Ahmed, M. U., Hussain, S., \& Farid, S. (2018). Factors Influencing the Adoption of e-Learning in an Open and Distance Learning Institution of Pakistan. Electronic Journal of e-Learning, 16(2), 148-158.

[24] Drennan, G. \& Moll, I. (2018). A Conceptual Understanding of how Educational Technology Coaches help Teachers Integrate iPad Affordances into their Teaching. Electronic Journal of e-Learning, 16(2), 122-133. 
[25] Jou, M., Lin, Y. T., \& Tsai, H. C. (2016). Mobile APP for motivation to learning: an engineering case. Interactive Learning Environments, 24(8), 2048-2057. https://doi.org/10.10 $\underline{80 / 10494820.2015 .1075136}$

[26] Sun, Z., Yao, X., You, J., Du, W., \& Luo, L. (2018). Detecting the correlation between mobile learning behavior and personal characteristics among elementary school students. Interactive Learning Environments, 26(8), 1023-1038. https://doi.org/10.1080/10494820. $\underline{2018.1428633}$

[27] Jaffar, M. A. y Musa R. (2019). Factorial Validation and Measurement Model of Attitude and Intention Towards Adoption of Islamic Financing Among Non-users. En F. Hassan, I. Osman y E.S. Kassim (eds.), Contemporary Management and Science Issues in the Halal Industry (pp. 65-76). Estados Unidos: Springer. https://doi.org/10.1007/978-981-13-2677$\underline{6} 6$

\section{Author}

Ricardo-Adán Salas-Rueda is a full-time researcher in the Instituto de Ciencias Aplicadas y Tecnología, Universidad Nacional Autónoma de México. PhD in New Technologies Design. Member of the National System of Researchers in Mexico (CONACYT) level I (2019-2021) and candidate (2016-2018). Research lines: Data Science and Educational Technology. ORCID: https://orcid.org/0000-0002-4188$\underline{4610}$

Article submitted 2019-11-09. Resubmitted 2020-01-10. Final acceptance 2020-01-11. Final version published as submitted by the authors. 